\title{
Do Accounting Programs at Saudi Universities Adopt Relevant Skills?
}

\author{
Qasim Zureigat \\ Professor of Accounting and Auditing at Sulaiman AlRajhi Colleges \\ AlQassim, Saudi Arabia \\ Email: q.zureigat [AT] sr.edu.sa
}

\begin{abstract}
This study aims at investigating wither accounting programs at Saudi universities incorporate relevant skills into its curriculum or not. The study utilizes International Educational Standards (IES), mainly standard 3 to identify the relevant skills for accounting graduates, as these standards represent internationally accepted standards for accounting education. Based on IES 3 structure and components, a questionnaire was developed and distributed to Saudi universities that offer accounting programs, and a total number of 111 questionnaires were revealed and analyzed. The results indicated that Saudi universities incorporate intellectual skills, technical and functional skills and interpersonal and communication skills into the curriculum of its accounting programs, while these programs lack both personal skills and organizational and business management skills. Such results support the lack of a comprehensive framework at Saudi universities for its accounting programs. The study recommends universities and regulators to deeply assess accounting programs at Saudi universities and to redesign its curriculum to meet the need for skilled and qualified accountants.
\end{abstract}

Keywords---- Accounting Programs, Skills, Universities, Saudi, International Education Standards

\section{INTRODUCTION}

The qualification of the accountant is one of the most important pillars of achieving the objectives of the financial reports. Several studies have followed the method of analyzing the relationship between personality variables and the efficiency of the accountant as a source for preparing the accounting information (Arther and Everaert, 2012). However, the complexity of business and globalization imposed on the accounting profession have raised the demand for high professional skills and continuous accounting education for accountants (Needle, 2010; Apriliana et al, 2017). The responsibility of preparing qualified accountants with professional skills rests with several bodies. The institutions of higher education are at the forefront of their development by adopting relevant training techniques based on competency in professional preparation, ie focusing on providing the learner with professional abilities and skills (IFAC, 1998). The professional organizations, most notably the International Federation of Accountants, need to move in their direction. As the traditional approach of many higher education institutions concerned with accounting education does not qualify the student to the extent required to practice the profession efficiently (Zureigat, 2015).

The criticisms that have been directed towards accounting education programs worldwide have led to the need to improve and control the quality of these programs to ensure the quality of its educational and professional outcomes. Several previous studies have pointed to criticisms of accounting education programs, which have shown a failure to meet professional requirements and lack of necessary skills that meet the rapid changes in the business world (Rezaee et al. 2018). These studies were conducted in different contexts including western countries (such as the United States, Britain, Australia) and eastern countries (such as China), revealing general dissatisfaction with the quality of accounting graduates (Liebtag, 1987; Albrecht and Sack, 2000; Nelson, et al, 2002; Burnett, 2003; Bui and Porter, 2010; Awayiga et al. 2010). These studies indicate that the outputs of accounting education have become inadequate to meet the requirements of the market of the accounting profession.

Such criticisms have been the drivers of the International Federation of Accountants (IFAC) to form the International Accounting Education Standards Board (IAESB) to begin issuing standards that aim at providing guidance to improve the quality of international accounting education programs. IAESB issued eight standards from its inception until November 2013, these standards include guidance on the general requirements for accounting education programs and the knowledge content of these programs, as well as the skills to be included in the accounting education programs which are listed in the International Standard of Education number 3. These skills are highly recommended to be considered by the accounting program as one of the most important elements that these programs should focus on (Howcroft, 2017).

Since accounting education programs are designed to prepare qualified graduates to join the labor market and the profession, many organizations are already interested in these programs and their development mechanisms. Many prestigious academic accreditation bodies such as The Association to Advance Collegiate Schools of Business (AACSB) dedicated its approach to business schools to develop the graduates of these colleges with professional qualifications to raise the level of skills acquired by students in these colleges and in a way that enables them to engage in the labor market, 
also the International Federation of Accountants IFAC has worked to pay attention to the develop accounting mechanisms through the issuance of a set of standards designed to improve the quality of accounting education according to international practices based on the requirements of the accounting profession by developing the International Accounting Education Standards Board (IAESB). Hence, this study is an attempt to assess the reality of accounting education in Saudi and its consistency with an important part of these international standards, which is determined by International Education Standards (IES) Standard No. (3), which deals with one of the most important outputs of accounting education globally, namely the skills of accounting students.

The consideration of the importance of skills in accounting education has become a necessity to be recognized and taken into account when designing accounting programs because of its importance in qualifying graduates of accounting to comply with the requirements of the labor market. In the United States, Frecka and Reckers (2010) mentioned that accounting graduates need to have critical thinking skills, communication skills, and written and oral skills during their accounting study. Thibodeau et al. (2012) asserted the need to focus on skills provided in accounting programs. Crawford et al. (2011) also pointed out the importance of determining the skills to be provided to accounting students in a manner consistent with the nature of the accounting profession. The study of Keneley and Jackling (2011) also pointed out the importance of the skills of accounting education programs, which shows the importance of building skills in accounting education programs methodically and based on specific frameworks.

In regard to the Saudi environment, different universities and colleges offer accounting education programs at different levels of study. The standards of the Education Accreditation Authority in Saudi Arabia do not adopt any standards that highlight the specifically require the content of the accounting programs or in business schools. Hence, the problem of this study is to investigate the extent to which the accounting education programs of the bachelor's degree in Saudi universities comply with the requirements of the International Education Standards (IAE) standard No. 3 that considers the skills of accounting programs graduates, the current study aims at answering the following question: To what extent are the skills involved in accounting education programs in Saudi universities to be consistent with the requirements of Standard No. (3) of the Accounting Education Standards?

\section{IMPORTANCE AND CONTRIBUTION}

The current study considers the importance of the skills that must be included in accounting education programs in general based on generally accepted standards which are IES. Several studies have addressed the importance of these skills and the need for them in accounting education programs (Thibodeau et al., 2012; Crawford et al., 2011; Keneley and Jackling 2011; Millron 2012; Willcoxson, et al., 2010; McPeak et al., 2012; Anis, 2018).

The current study follows the International Education Standards (IES) guidelines to link the international trends of the skills required for accounting graduates to the ones in a developing country namely Saudi Arabia, where this study can be considered as one of the few studies that will provide useful information for both Saudi universities and the Saudi legislator in the Saudi higher education sector. In addition, this study will be one of the studies that consider a framework of skills required for accounting programs, and unlike many previous studies in this field, most of which worked on a specific skill without taking into account the total integrated of these skills.

\section{LITERATURE REVIEW}

The profession of accounting can be seen as one of the professions that must cope with developments in the business environment through the nature of the skills that must be available for accounting graduates, starting from their initial qualification in the accounting education programs that should consider these skills into account (Jackling and Lange, 2008). There have been numerous studies on the area of accounting education skills, many of which are the reality of accounting education in many countries where we find the study of Awayiga, et al. (2010) that aimed to assess accounting education in Ghana, and the importance it according to the perspectives of employers and graduates. This study sought to explore the knowledge and skills that accountants must have in Ghana. The results of the study showed a gap between accounting education and the work environment. There is also consensus among employers and accounting graduates that different skills should be included in education programs. Both graduates and employers considered that the skills of analysis and thinking were the most important among the professional skills that accountants must have. Graduates considered that technical and functional skills were the least important, while employers considered communication skills to be the least important.

Lin (2008) aims at identifying the knowledge and skill components that are required in China's accounting curricula to meet the challenges of the changing business environment. The study sample consisted of 396 accounting students, faculty members and practitioners from three major cities in China. The study identified 6 areas of knowledge and skills to include it in the curricula of accounting education, these areas are managerial skill, management knowledge, and knowledge in the essence of accounting, personal characteristics, Techniques and basic skills. Jackling and Lang (2009) examined the 
technical and soft skills involved in university accounting content from the perspective of graduates and employers in Australia and concluded that employers believe that accounting graduates do have the technical skills of accounting practices and procedures but they lack general skills such as teamwork, leadership, language communication and interpersonal communication skills.

The study of (Needle JR, 2010) examined the impact of globalization on accounting education and showed that there is a significant impact of globalization on accounting education. This impact not only on educational content but also on the demand for qualified students and teachers. However, the study found that there is no possibility of moving toward accounting education in the global environment because of the existence of different standards-setting bodies that issue different accounting standards.

Jones and Abraham (2009) focused on researching emotional intelligence skills in teaching and learning of accounting students by providing an educational environment that helps accounting graduates get jobs. The study concluded that the emotional intelligence and skills required for graduates of accounting should be included in order to be able to develop their ability to succeed in the advanced work environments. The study also concluded that the assessment tools should be used to determine the level of emotional intelligence of accounting students and to determine the nature of the knowledge and skills to be included in accounting education and training programs.

McPeak et al. (2012) aimed to introduce the International Education Standards (IES), which were developed by the International Accounting Education Standards Board (IAESB). The study found that there are major factors influencing the development and application of these standards. The study concluded that the different cultures, languages and social systems of the people around the world are critical factors that affect accounting education. Zureigat \& Alazzam (2014) investigated the adopting of IES 3 by accounting programs in Jordan. Using a questionnaire developed according to this standards, they found that Jordanian universities are not fully adopting all of the skills included in the IES. Their study is one of the leading studies in the MENA region that consider the adoption of IES. Moreover, they concluded that there are significant differences between public and private universities in the level of including IES NO 3 components into its curriculum.

\section{HYPOTHESES DEVELOPMENT}

The skills required by the International Education Standard (IES) No. 3 were defined as follows:

1. Intellectual skills: A set of skills that will enable the professional accountants to solve problems and make decisions with good governance in complex organizational situations, and is consisted of six skills pillars: knowledge, understanding, application, analysis, synthesis, and evaluation.

2. Technical and functional skills: These skills include accounting skills, quantitative skills, measurement, reporting, and others accounting related skills.

3. Personal skills: It relates to the attitudes and behavior of the accountant, such as self-management, initiative, influence, self-learning, and others.

4. Interpersonal and communication skills: a set of skills that enable the accountant to work for the general interest of the organization, such as consultation with others, working within the team, negotiation, and others.

5. Organizational and business management skills: It is a set of skill that enables the accountant to contribute to decision making, such as leadership, professional judgment and the ability to organize and delegate duties.

Based on the study's question and its objectives, the hypotheses of the study were formulated as follows:

H0-1: Bachelor accounting programs at Saudi universities do not offer intellectual skills.

H0-2: Bachelor accounting programs at Saudi universities do not offer technical and functional skills.

H0-3: Bachelor accounting programs at Saudi universities do not offer personal skills.

H0-4: Bachelor accounting programs at Saudi universities do not offer interpersonal and communication skills.

H0-5: Bachelor accounting programs at Saudi universities do not offer organizational and business management skills.

\section{METHODOLOGY}

\subsection{Data Collection}

The study adopts a questionnaire to collect the needed data. A questionnaire including the skills listed by IES (3) was designed to collect the initial data needed to test the hypotheses. The first part of the questionnaire aims at obtaining general information about the characteristics of the study sample. The other sections aimed to determine the reality of the skills provided by the accounting programs and the skills that are included in these programs and its curriculum. 


\subsection{Study Population}

In order to achieve the objectives of this study, the study population was determined by all faculty members in accounting specialization in Saudi universities. Unfortunately, there are no available statistics about the number of those faculty members or about their distribution among Saudi universities and colleges, which led to distribute the questionnaire to all Saudi universities and asked them to communicate the questionnaire to its accounting departments and accordingly to all faculty members in these departments. After two months of collecting the responses, only 111 valid responses were recovered.

\subsection{Validation and Reliability}

For the purposes of verifying the validity of the study, the questionnaire was presented to a group of Saudi university professors. The total number of professors was three professors who were asked to assess the ability to understand and recognize the concepts and phrases contained in this questionnaire. The notes that were received from the reviewers were considered and changes were implemented to make sure that the questionnaire is valid.

Regarding the reliability of the questionnaire, the internal consistency coefficient (Cronbach Alpha) was used to determine the consistency of the questionnaire. The results of Cronbach Alpha Test were all more than 60\% and range from $71 \% \%$ to $92 \%$, which indicate the reliability of the questionnaire.

\section{STATISTICAL ANALYSIS}

\subsection{Preliminary Analysis}

This section presents the results of the statistical analysis for the sample responses. Table (1) shows the characteristics of the study sample in terms of academic rank and years of experience the academic.

Table 1: Characteristics of Sample

\begin{tabular}{c|c|c}
\hline Academic Rank & Frequency & Percent \\
\hline Assistant Professor & 44 & $40 \%$ \\
Associate Professor & 35 & $31 \%$ \\
Professor & 32 & $29 \%$ \\
\hline Experience & Frequency & Percent \\
\hline Less than 5 years & 23 & $44 \%$ \\
5-10 Years & 49 & $26 \%$ \\
10-15 Years & 29 & $9 \%$ \\
\hline More than 15 Years & 10 & $21 \%$ \\
\hline
\end{tabular}

The figures presented in Table 1 above show that $40 \%$ of the respondents are assistant professors and $31 \%$ of them are associate professors, while the proportion of professors who answered the questionnaire is $29 \%$. At the meanwhile, years of experience data show that almost $80 \%$ of the sample have academic experience more than five years in accounting education, which indicates the ability of this sample to answer the questionnaire as they have relevant academic experiences and ranks.

Table (2) in the following section shows the mean and standard deviations of the sample's responses regarding wither the skills included in IES 3 are embedded in accounting programs in Saudi universities.

Table 2: Descriptive Statistics for Questionnaire responses

\begin{tabular}{c|c|c}
\hline Paragraph Questions & Mean & Standard Deviation \\
\hline Intellectual skills & 3.621 & 0.17 \\
Technical and functional skills & 3.498 & 0.24 \\
Personal skills & 2.341 & 0.48 \\
Interpersonal and communication skills & 3.203 & 0.21 \\
Organizational and business management skills & 2.419 & 0.53 \\
\hline
\end{tabular}

A review of the descriptive statistics in Table 2 above shows that intellectual skills, technical and functional skills, interpersonal skills and communication skills are the skills that are more likely included in accounting programs as the means of the responses are higher than 3. In terms of personal skills and organizational and managerial skills, we find that the means of the responses are less than 3, which indicate the lack of inclusion of these skills in the accounting programs in the Saudi universities. 
At the meanwhile, the study implemented a normality test in order to make sure that the researcher can implement parametric tests throughout the statistical analysis. One Sample K-S test is utilized to identify wither the data follows the assumptions of the normal distribution or not. The results of (One Sample K-S) shows significant values for all variables are greater than 0.05 , which indicate that the data is normally distributed and the study can implement parametric tests.

\subsection{Results and Discussions}

The study utilizes One-sample T-Test to test the hypotheses of the study and find the results. The test value is (3) which is the median value for the questionnaire answers.

First hypothesis:

This hypothesis considers the intellectual skills provided by the third standard of international education standards. Table (3) below presents the results of the T-test for this hypothesis, where the (T) value is (18.37) at the level of significance (0), leading to a conclusion that the accounting programs in the Saudi universities offers the intellectual skills to its students and include these skills in its accounting curriculum. Such a result is consistent with (Awayiga, et al.2010).

Table 3: Results of testing the first Hypothesis

\begin{tabular}{c|c}
\hline T Value & Significance \\
\hline 18.37 & 0.000 \\
\hline
\end{tabular}

Second Hypothesis:

The second hypothesis investigates wither accounting programs at Saudi universities incorporate the technical and functional skills provided by IES 3 in its curriculum or not. Table (4) below presents the results of the T-test that conclude the adoption of the technical and functional skills that include computer skills, mathematical and statistical applications, and measurement, by accounting programs in Saudi universities. This result is in line with (Jackling and Lang, 2009) which was conducted in the Australian environment.

Table 4: Results of testing the Second Hypothesis

\begin{tabular}{c|c}
\hline T Value & Significance \\
\hline 15.46 & 0.000 \\
\hline
\end{tabular}

Third Hypothesis:

This hypothesis sought to test the extent to which accounting programs offered by Saudi universities consider the personal skills throughout its curriculum. The results of the T-test presented in Table (5) show that these programs do not provide the personal skills as described by IES 3. The negative value of T (- 6.459) at a significant level (0.001) indicates that accounting programs do not offer personal skills that include self-management skills, initiative, priorities development and ethics, leading to accept the third null hypothesis. This result confirmed the result of (Jackling and Lang, 2009).

Table 5: Results of testing the third hypothesis

\begin{tabular}{c|c}
\hline T Value & Significance \\
\hline-6.459 & 0.001 \\
\hline
\end{tabular}

Fourth hypothesis:

This hypothesis aims to investigate wither accounting programs adopt personal and communication skills. Table (6) shows the result of the T-test for this hypothesis, in which the fourth null hypothesis can be rejected and conclude that accounting programs in Saudi universities do provide the students with the personal and communication skills as listed by IES 3. This result is also consistent with the findings of Jackling and Lang (2009).

Table 6: Results of testing the fourth hypothesis

\begin{tabular}{c|c}
\hline T Value & Significance \\
\hline 2.51 & 0.023 \\
\hline
\end{tabular}

Fifth hypothesis:

This hypothesis is concerned with organizational and business management skills that are listed in IES 3, and wither Saudi university incorporate it into its accounting programs. Table (7) below presents the results of T-test which lead to accepting of the fifth null hypothesis and conclude that accounting programs in the Saudi universities do not offer these 
skills that include skills, which include skills of strategic planning, leadership, personnel management, and project management. The result is consistent with the findings of (Jackling and Lang, 2009; Anis, 2018).

Table 7: Results of testing the fifth hypothesis

\begin{tabular}{c|c}
\hline T Value & Significance \\
\hline-5.012 & 0.001 \\
\hline
\end{tabular}

\section{CONCLUSION}

Accounting education has recently been criticized by professional bodies and employers due to the lack of harmonization of the outputs of the accounting programs for the requirements of the profession and the market (Webb, J., \& Chaffer, 2016), especially with regard to the skills that accountants must possess to carry out their work in accordance with the business environment in which companies operate.. As a response to such problems, IFAC has worked to produce international standards for accounting education to serve as guidelines for the best practices that accounting programs must adapt to equip graduates with the relevant skills that enable them to meet the labor market requirements.

Considering the accounting education in emerging countries, including Saudi Arabia, we find an increase in the number of programs offered by universities in the field of accounting which reflects the need of the labor market to graduates who acquire relevant skills for the accounting profession. This has raised the need for more research on skills provided by accounting programs and the extent to which they are in line with international best practices in this field. This study explored the reality of the skills provided by the accounting programs in Saudi universities based on the International Education Standards and mainly standard 3 that consider the skills needed for accounting graduates. The results of this study showed that the accounting education programs in the Saudi universities provide intellectual skills, technical and functional skills and interpersonal and communication skills, while these programs lack both personal skills, and organizational and business management skills, indicating that there is a weakness in the outputs of these programs at the higher education sector in Saudi Arabia.

Based on such findings, the study recommends the need to review the accounting programs in Saudi universities through an integrated approach based on best practices and international standards in accounting education as a guide for building such programs, such as AACSB, which have proven to be very effective in raising the quality of business education. The study also recommends that the Ministry of Education has to work for raising the standards of accreditation applied to Saudi universities qualitatively and not only keep sticking to quantitative standards of accreditation. The study also recommends the need to continue researching issues related to accounting and business education and move to international benchmarking with business schools that already have played their role in developing the capabilities of its graduates.

\section{REFERENCES}

[1] Albrecht, W. S., and Sack, R. J. 2000. Accounting education: charting the course through a perilous future, 2000. American Accounting Association, Sarasota, FL.

[2] Anis, A. (2017). Auditors' and accounting educators' perceptions of accounting education gaps and audit quality in Egypt. Journal of Accounting in Emerging Economies, 7(3), 337-351.

[3] Apriliana, T., Rediyanto, T., Indriyani, V., \& Utama, A. A. G. S. (2017). Accounting Education Based on Finance Record Training to Increase Revenue from SMEs in Tamansari, Banyuwangi-Indonesia. Advanced Science Letters, 23(9), 8857-8859.

[4] Arthur, N., and Everaert, P. 2012. Gender and performance in accounting examinations: exploring the impact of examination format. Accounting Education. 21(5): 471-487.

[5] Awayiga, J. Y., Onumah, J. M., and Tsamenyi, M. 2010. Knowledge and skills development of accounting graduates: The perceptions of graduates and employers in Ghana. Accounting Education: an international journal. 19(1-2): 139158.

[6] Bui, B., and Porter, B. 2010. The expectation-performance gap in accounting education: an exploratory study. Accounting Education: an international journal. 19(1-2): 23-50.

[7] Burnett, S. 2003. The future of accounting education: A regional perspective. Journal of Education for Business, 78(3), 129-134.

[8] Crawford, L., Helliar, C., and Monk, E. A. 2011. Generic skills in audit education. Accounting Education: An International Journal. 20(2): 115-131.

[9] Frecka, T. J., and Reckers, P. M. J. 2010. Rekindling the debate: What's right and what's wrong with masters of accountancy programs: The staff auditor's perspective. Issues in Accounting Education. 25(2): 215-226.

[10] Howcroft, D. (2017). Graduates' vocational skills for the management accountancy profession: exploring the accounting education expectation-performance gap. Accounting Education, 26(5-6), 459-481. 
[11] IFAC Education Committee. 1998. Discussion paper: Competence-Based Approaches to the Professional Preparation of Accountants, www.IFAC.org/store/category.tmpl? category=Education/. PP18-20. Accessed on line Feb 2014.

[12] International Federation of Accountants (IFAC). 1996. Education Committee. IEG 9 prequalification education, assessment of professional competence and experience requirements of professional accountants New York: IFAC.

[13] Jackling, B., and De Lange, P. 2009. Do accounting graduates' skills meet the expectations of employers? A matter of convergence or divergence. Accounting Education: an international journal. 18(4-5): 369-385.

[14] Jones, G., and Abraham, A. 2009. The Value of Incorporating Emotional Intelligence Skills in the Education of Accounting Students. Australasian Accounting Business and Finance Journal. 3(2).

[15] Keneley, M., and Jackling, B. 2011. The acquisition of generic skills of culturally-diverse student cohorts. Accounting Education: An International Journal. 20(6): 605-623.

[16] Liebtag, B. 1987. Compensation curves. Journal of Accountancy. 164(4): 75-79.

[17] Lin, Z. J. 2008. A factor analysis on knowledge and skill components of accounting education: Chinese case. Advances in Accounting. 24(1): 110-118.

[18] McPeak, D., Pincus, K. V., and Sundem, G. L. 2012. The International Accounting Education Standards Board: Influencing global accounting education. Issues in Accounting Education. 27(3): 743-750.

[19] McPeak, D., Pincus, K. V., and Sundem, G. L. 2012. The international accounting education standards board: influencing global accounting education. Issues in Accounting Education. 27(3): 743-750.

[20] Milliron, V. C. 2012. CPAs explore a pre-certification pathway to excellence. The Accounting Educators' Journal. 22: 43-71.

[21] Needles Jr, B. E. 2010. Accounting education: The impact of globalization. Accounting Education: an international journal. 19(6): 601-605.

[22] Nelson, I. T., Vendrzyk, V. P., Quirin, J. J., and Allen, R. D. 2002. No, the sky is not falling: evidence of accounting student characteristics at FSA schools, 1995-2000. Issues in Accounting Education. 17(3): 269-287.

[23] Rezaee, Z., Wang, J., \& Lam, B. (2018). Toward the integration of big data into forensic accounting education. Journal of Forensic and Investigative Accounting, 10(1).

[24] Thibodeau, J. C., Levy, E., and Osterheld, K. K. 2012. A supplementary evening program for students in the introductory financial accounting course. Advances in Accounting Education. 13: 23-40.

[25] Webb, J., \& Chaffer, C. (2016). The expectation performance gap in accounting education: A review of generic skills development in UK accounting degrees. Accounting Education, 25(4), 349-367.

[26]Zureigat, Q. M. (2015). Accounting Graduates Skills and Employers' Needs: The Saudi Case. Jordan Journal of Business Administration, 11(1), 227-238.

[27]Zureigat, Q., \& Alazzam, E. (2014). The Reality of Accounting Education Programs in the Jordanian Universities and Compatibility with the Requirements of International Education Standards (IES3). The Arab Journal of Accounting, 17(02), 103-124. 